International Journal of Advanced Technology in Mechanical, Mechatronics and Materials

(IJATEC)

Vol. 01, No. 2 (2020) 56-65

(C) Institute for Research on Innovation and Industrial System (IRIS)

\title{
Application of Vendor Managed Inventory Cooperation Model to Encourage Distribution of Products in Ud. Sari Jaya
}

\author{
Andary Asvaroza Munita*a, Muhammad Kholila, Muhammad Galih Raka Siwi ${ }^{\text {b }}$, Adizty \\ Suparno ${ }^{b}$ \\ a Department of Industrial Engineering, Faculty of Engineering, Universitas Mercu Buana, Jakarta, Indonesia \\ bIndustrial Engineering Bachelor Programme, Faculty of Engineering, Universias Mercu Buana, Indonesia
}

\begin{abstract}
UD. Sari Jaya is a home industry that produces cassava and other tubers into chips. Cassava chips are the main product because of their high level of consumer interest in the product compared to others-the Problems faced by UD. Sari Jaya is that they are unable to meet the market demand more effectively. In the process of providing the needs, UD. Sari Jaya often performs several deliveries to each stall caused by the lack of product availability at the stall, causing demand to be unfulfilled. The number of Retailers to be served, the lack of information on needs is one of the obstacles in the process of inventory replenishment. Vendor Managed Inventory (VMI) is one of the Collaboration Model in the supply chain between producers and retailers where collaboration is expected to make arrangements regarding the number of lot sizes order as well as the frequency of deliveries to each stall with a minimum total cost, by thus UD. Sari Jaya can have reasonable control in the process of fulfilling the needs of this Cassava Chips.
\end{abstract}

Keywords: Vendor Managed Inventory (VMI); collaboration; replenishment

DOI: $10.37869 /$ ijatec.v1i2.15

Received 19 March 2020; Accepted 6 August 2020; Available online 7 August 2020

(C) 2020 IRIS Publisher. All rights reserved.

\section{Introduction}

With the development of various industrial sectors in Indonesia, it is indistinguishable from the emergence of many small industries that originated from within the country. Efforts to improve and develop small industries need more considerable attention to promote regional economic growth. With the advent of such small industries, it certainly creates new jobs and thereby contributes to opportunities to reduce unemployment in the region.

UD. Sari Jaya is one of the domestic industries producing cassava chips in Depok, West Java. In addition to cassava chips, the domestic industry is UD. Sari Jaya also processes potatoes and macaroni as offered product variations. One of the obstacles is regulating the availability of goods to ensure the sustainability of sales against cassava chips as a distribution channel. The actual state occurs between UD. Sari Jaya, with these stalls as retailers, will not get benefit from the stall due to sales errors, as each stall is often out of stock. The sales errors are due to a lack of coordination and information from the stall to the supplier. As a result, there is no planned volume or frequency of delivery, resulting in ineffective processes and additional losses for both parties. Vendor Managed Inventory (VMI) is one of a collaborative model that is considered suitable for managing inventory and shipping products to facilitate the distribution of these Cassava Chips products. VMI is an industrial policy approach to bring together and coordinate all stakeholders in the supply chain [7]. With VMI, suppliers manage retailer inventory by specifying the retailer's replenishment volume and time intervals by accessing the availability and demand volume of goods that the retailer needs to meet [3]. 


\section{Research Methodology}

In conducting research, research steps are needed to facilitate the writer in achieving his goals. This research was conducted on the distribution system of Cassava Chips Products in the UD Sari Jaya home industry. Where the products produced are marketed through retailers of stalls in the Depok Region, West Java, the total is 50 stalls.

The actual system observed is a traditional system where the problem occurs due to the ineffectiveness of delivery caused by the absence of information about the needs of consumers and the number of stalls to be served. In the second condition, the VMI model is tried to be implemented where the supplier takes control in planning the Purchaser inventory. As a result, the Buyer no longer bears full costs of ordering and costs as a result of the collaboration. On the supplier's side, by applying VMI, the management of product distribution is more effective, and guarantees of sales can be known even though as an impact Suppliers must bear the administrative costs of order to the Buyer, and still bear the costs of the shortage as a penalty for deficiencies that occur.

The demand faced by the supplier is probabilistic because even though there is a sharing of information from the Buyer, the supplier still cannot know the actual condition of the sale of the cassava chips. The brief frame of mind used in this study can be seen in Figure 1.

\begin{tabular}{|c|c|c|c|c|}
\hline ISSUES & INPUT & PROCESS & OUTPUT & OBJECTIVE \\
\hline $\begin{array}{l}\text { - The process of } \\
\text { delivering } \\
\text { finished goods to } \\
\text { buyers is } \\
\text { irregular } \\
\text { - Cannot } \\
\text { determine buyer } \\
\text { needs } \\
\text { - Lack of } \\
\text { information } \\
\text { related to buyer } \\
\text { needs }\end{array}$ & $\begin{array}{l}\text { - Supplier } \\
\text { message } \\
\text { charges } \\
\text { - Supplier } \\
\text { save costs } \\
\text { - Buyer } \\
\text { message } \\
\text { charge } \\
\text { - Buyer save } \\
\text { costs }\end{array}$ & $\begin{array}{l}\text { - Calculations } \\
\text { using the } \\
\text { Traditional } \\
\text { Model } \\
\text { - Calculations } \\
\text { using the } \\
\text { VMI Model }\end{array}$ & $\begin{array}{l}\text { - Economical lot } \\
\text { sizes for } \\
\text { suppliers and } \\
\text { buyers } \\
\text { - Optimal shipping } \\
\text { frequency } \\
\text { - Total costs for } \\
\text { suppliers, buyers, } \\
\text { and systems }\end{array}$ & $\begin{array}{l}\text { - Guarantee the } \\
\text { availability of } \\
\text { goods to the } \\
\text { buyer } \\
\text { - Suppliers can } \\
\text { reduce } \\
\text { uncertainty on } \\
\text { the buyer side } \\
\text { - Regular } \\
\text { delivery } \\
\text { frequency }\end{array}$ \\
\hline
\end{tabular}

Figure 1. Research framework

The problems identified are irregular delivery of the finished product to the Buyer, who cannot determine the Buyer's needs, and lack of information related to the Buyer's needs. Inputs include supplier message costs, supplier savings costs, buyer order costs, and buyer savings costs. The processes performed are calculations using the traditional model and calculations using the VMI model. The output achieved is the size of the economic order of the Buyer and supplier, the optimal shipping frequency, and the total cost of the supplier, Buyer, and system. The supplier can reduce the uncertainty on the part of buyers and the frequency of regular deliveries concerning the goals achieved to make goods available to buyers.

\section{Results and Discussions}

Based on monthly data obtained from 50 stalls demand of Cassava chips at UD Sari Jaya retailer shows in Table 1.

Table 1. The Demand for cassava chips

\begin{tabular}{clcclc}
\hline No. & List of Stall & $\begin{array}{c}\text { Demand Per } \\
\text { Month }\end{array}$ & No. & \multicolumn{1}{c}{ List of Stall } & $\begin{array}{c}\text { Demand Per } \\
\text { Month }\end{array}$ \\
\hline 1 & Wr. Wati & 240 & 26 & Wr. Kelontong Ibu Nuryanti & 600 \\
2 & Wr. Lestari & 240 & 27 & Wr. Kelontong Esa & 600 \\
3 & Wr. Lokes Psr lama & 480 & 28 & Wr. Kelontong Mulya & 600 \\
4 & Wr. Dodo Psr kemiri & 360 & 29 & Wr. Kelontong Ar Raihan & 480
\end{tabular}




\begin{tabular}{rlllll}
5 & Wr. Iwan Psr kemiri & 480 & 30 & Wr. Sembako Bpk Wardi & 600 \\
6 & Wr. Luna Psr kemiri & 600 & 31 & Wr. Kelontong Barokah & 600 \\
7 & Wr. Gun 1 Psr kemiri & 600 & 32 & Wr. Kelontong Sugiti & 360 \\
8 & Wr. Gun 2 Psr kemiri & 360 & 33 & Wr. Sembako Murni & 480 \\
9 & Wr. Asep Psr kemiri & 480 & 34 & Wr. Mba Ajeng & 360 \\
10 & Wr. Triyanto Psr Baru & 480 & 35 & Wr. Kelongont Lima Jaya & 480 \\
11 & Wr. Dpk 2 Tengah & 600 & 36 & Wr. Sembako Ibu Nyai & 480 \\
12 & Wr. Sumber Rezeki Snack & 480 & 37 & Wr. Sembako Sumber rezeki & 600 \\
13 & Wr. Snack Kukusan Beji & 360 & 38 & Wr. Kelontong H. Sueb & 600 \\
14 & Wr. Lulu & 600 & 39 & Wr. Bakti Jaya & 480 \\
15 & Wr. Sembako Ibu Hj. Yoyoh & 600 & 40 & Wr. Lima Saudara & 240 \\
16 & Wr. Sembako Grosir Bhaki Karya & 600 & 41 & Wr. Minoriya & 360 \\
17 & Wr. Ko Hasan & 360 & 42 & Wr. Bpk Wardi & 480 \\
18 & Wr. Sinar Baru & 240 & 43 & Wr. Ucok & 360 \\
19 & Wr. Sembako YKS & 600 & 44 & Wr. Sembako Kalimantan & 480 \\
20 & Wr. El Shirazy & 480 & 45 & Wr. Madura & 480 \\
21 & Wr. Murni & 360 & 46 & Wr. Yuliana \\
22 & Wr. Tri Jaya & 480 & 47 & Wr. Kelontong Dalimunthe & 240 \\
23 & Wr. Bhakti Karya & 480 & 48 & Wr. Empat Bersaudara & 480 \\
24 & Wr. Kelontong Abi & Wr. Kelontong Yadi & 49 & Wr. Kelontong Tasya Kembang & 480 \\
\hline
\end{tabular}

\subsection{The parameters used}

1. Supplier Order Cost

Supplier Order Cost represents the costs incurred by UD. Sari Jaya each time ordering raw materials, which is Rp. 30,000 per order.

2. Supplier Holding Cost

It is a cost for storing raw materials to be able to meet the number of Warung requests, which is Rp. 100. The saving cost components are warehouse rental costs, electricity costs, and labor costs.

3. Buyer Order Cost

Buyer Order Cost represents the cost incurred by each stall per one-time order. The amount of the order cost for each stall is assumed to be the same, that is Rp. 17,000 per order. The cost of this order consists of the cost of ordering \& shipping as well as product ownership costs.

4. Buyer Holding Costs

The saving cost for each is assumed to be the same, which is $10 \%$ of the electricity cost, which is Rp. 15,000, which is charged to the number of needs in each stall.

\subsection{Calculation of the Traditional Model supplier inventory policy}

The Traditional Model is an initial condition of the system, which is observed where the number of supplier requests is a determination of the supplier's capacity in each shipment, which is $200 \mathrm{~kg}$ per shipment. The Notation and parameters used are as follows:

1. Notation:

a. Decision Variable

$Q_{p} \quad$ : Lot size of supplier order $(\mathrm{kg})$

b. Parameter

$D \quad$ : The level of supplier demand $=200 \mathrm{~kg}$

$A_{p} \quad:$ The total cost of supplier order $=$ Rp. $30,000 /$ order

$P_{p} \quad$ : Price of raw material per $\mathrm{kg}=\mathrm{Rp} .3,000 / \mathrm{kg}$

$h_{p} \quad:$ Holding cost of finished product $=$ Rp. $100 / \mathrm{pcs} / \mathrm{month}$

$\mathrm{Cu}_{p} \quad$ : Shortage cost from supplier to buyer $=\mathrm{Rp} .750 / \mathrm{kg}$ 


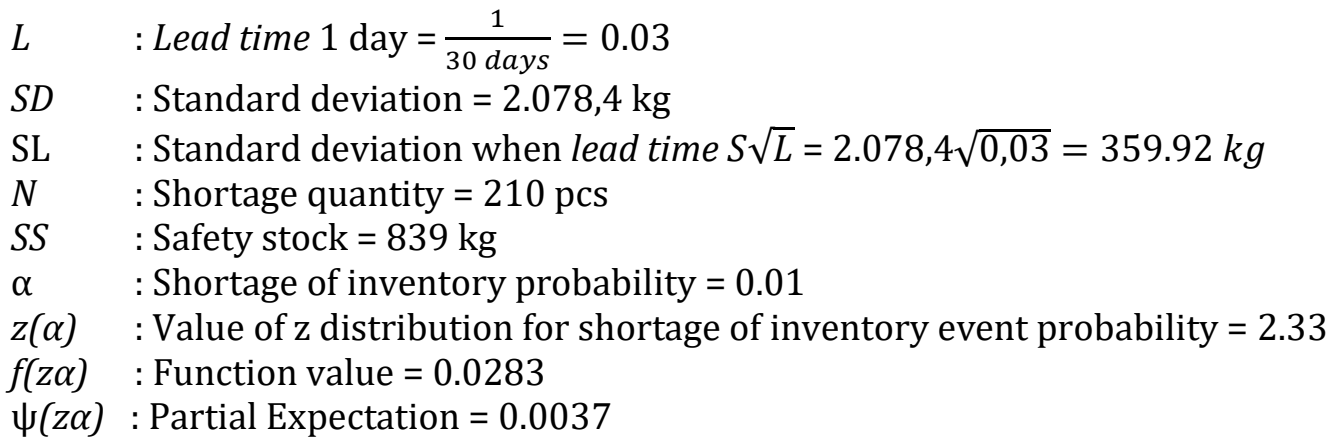

2. Calculate the Economical Order Lot Size for Suppliers $\left(Q_{p} *\right)$

$$
\begin{array}{rl}
Q_{p} & *=\sqrt{\frac{2 D\left(A_{p}+C_{u} N\right)}{h_{p}}} \\
Q_{p} & *=\sqrt{\frac{2 \times 200(30.000+750 \times 210)}{100}} \\
& =866.02 \approx 866 \mathrm{~kg} \text { per month }
\end{array}
$$

3. Calculate Total Supplier Costs

Total supplier cost $=$ Order cost + Holding cost + Shortage cost

$=\left(\frac{\text { demand level }}{\text { order lot size }} \times\right.$ order cost per order $)+($ average inventory at supplier $\times$

holding cost per pcs/periode $)+($ shortage quantity $\times$ shortage cost to buyer $)$

$$
\begin{aligned}
& =\left(\frac{D}{Q_{p}} A_{p}\right)+\left(h_{p}\left(\frac{1}{2} Q_{p}+S S\right)\right)+\left(\frac{C u_{p} D N}{Q_{p}}\right) \\
& =\left(\frac{200}{866} 30.000\right)+\left(100\left(\frac{1}{2} 866+839\right)\right)+\left(\frac{750 \times 200 \times 210}{866}\right) \\
& =R p .170,502.53 \approx \text { Rp. } 170,503 \text { per month }
\end{aligned}
$$

\subsection{Calculation of the Traditional Model of the buyer's inventory policy}

The traditional condition of the Buyer or stall is that the stall's needs are not known with certainty, which results in a shortage condition when the availability of the product is entirely run out before the day of delivery. The following calculation is carried out for each Warung to find out the Order Lot in each Warung in the Initial Condition based on the number of needs that must be fulfilled. The following calculation is an example of a calculation using the First stall Data (Wr. Wati).

1. Notation:

a. Decision Variable

$$
Q_{b} \quad \text { : Buyer order lot size (pcs) }
$$

b. Parameter

$$
\begin{array}{ll}
D & : \text { Demand level of buyer }=240 \text { pcs } \\
A_{p b} & : \text { Administration order cost }=\text { Rp.10,000/order } \\
A_{u b} & : \text { Transportation cost }=\text { Rp.1,000/order } \\
A_{k b} & : \text { Product ownership cost }=\text { Rp. } 6,000 / \text { pack } \\
A_{b} & : \text { The total cost of the Buyer's order }=\text { Rp. } 17,000 / \text { order } \\
P_{b} & : \text { Product purchase price }=\text { Rp. } 24,000 / \text { pack } \\
h_{b} & : \text { Finished product holding cost }=\text { Rp. } 63 / \mathrm{pcs} / \text { month } \\
C u_{b} & : \text { Shortage cost of buyer }=\text { Rp. } 4.6 / \text { pcs } \\
L & : \text { Lead time } 1 \text { day }=\frac{1}{30 \text { days }}=0.03 \\
S D & : \text { Standard deviation }=800 \text { pcs } \\
\text { SL } & : \text { Standard deviation when lead time } S \sqrt{L}=800 \sqrt{0.03}=138.64 \text { pcs } \\
N & : \text { Shortage quantity }=216 \text { pcs } \\
S S & : \text { Safety stock }=261 \text { pcs } \\
\alpha & : \text { Shortage of inventory probability }=0.03 \\
z(\alpha) & : \text { Value of z distribution for shortage of inventory event probability }=1.88
\end{array}
$$


$f(z \alpha) \quad$ : Function value $=0.0790$

$\psi(z \alpha):$ Partial Expectation $=0.0143$

2. Calculating Buyer's Economic Order Quantity $\left(Q_{b} *\right)$

$$
\begin{aligned}
Q_{b} & =\sqrt{\frac{2 D\left(A_{b}+C_{b} N\right)}{h_{b}}} \\
Q_{b} * & =\sqrt{\frac{2 \times 240(17,000+41.6 \times 216)}{63}} \\
& =\sqrt{198,095.23}=447 \text { pcs per month }
\end{aligned}
$$

The results of the calculation of the size of an economic order lot for other stalls can be seen in Table

\begin{tabular}{|c|c|c|c|c|c|c|c|}
\hline No. & List of Stall & $\begin{array}{l}\text { Demand } \\
\text { Per } \\
\text { Month } \\
\end{array}$ & $\begin{array}{c}\text { Buyer's } \\
\text { Economic Order } \\
\text { Quantity } \\
\end{array}$ & No. & List of Stall & $\begin{array}{c}\text { Demand } \\
\text { Per } \\
\text { Month } \\
\end{array}$ & $\begin{array}{c}\text { Buyer's } \\
\text { Economic } \\
\text { Order Quantity } \\
\end{array}$ \\
\hline 1 & Wr. Wati & 240 & 447 & 26 & $\begin{array}{l}\text { Wr. Kelontong Ibu } \\
\text { Nuryanti }\end{array}$ & 600 & 994 \\
\hline 2 & Wr. Lestari & 240 & 447 & 27 & Wr. Kelontong Esa & 600 & 994 \\
\hline 3 & Wr. Lokes Psr lama & 480 & 813 & 28 & $\begin{array}{l}\text { Wr. Kelontong } \\
\text { Mulya }\end{array}$ & 600 & 994 \\
\hline 4 & $\begin{array}{l}\text { Wr. Dodo Psr } \\
\text { kemiri }\end{array}$ & 360 & 630 & 29 & $\begin{array}{l}\text { Wr. Kelontong Ar } \\
\text { Raihan }\end{array}$ & 480 & 813 \\
\hline 5 & $\begin{array}{l}\text { Wr. Iwan Psr } \\
\text { kemiri }\end{array}$ & 480 & 813 & 30 & $\begin{array}{l}\text { Wr. Sembako Bpk } \\
\text { Wardi }\end{array}$ & 600 & 994 \\
\hline 6 & $\begin{array}{l}\text { Wr. Luna Psr } \\
\text { kemiri }\end{array}$ & 600 & 994 & 31 & $\begin{array}{l}\text { Wr. Kelontong } \\
\text { Barokah }\end{array}$ & 600 & 994 \\
\hline 7 & $\begin{array}{l}\text { Wr. Gun } 1 \text { Psr } \\
\text { kemiri }\end{array}$ & 600 & 994 & 32 & $\begin{array}{l}\text { Wr. Kelontong } \\
\text { Sugiti }\end{array}$ & 360 & 630 \\
\hline 8 & $\begin{array}{l}\text { Wr. Gun } 2 \text { Psr } \\
\text { kemiri }\end{array}$ & 360 & 630 & 33 & $\begin{array}{l}\text { Wr. Sembako } \\
\text { Murni }\end{array}$ & 480 & 813 \\
\hline 9 & Wr. Asep Psr kemiri & 480 & 813 & 34 & Wr. Mba Ajeng & 360 & 630 \\
\hline 10 & $\begin{array}{l}\text { Wr. Triyanto Psr } \\
\text { Baru }\end{array}$ & 480 & 813 & 35 & $\begin{array}{l}\text { Wr. Kelongont } \\
\text { Lima Jaya }\end{array}$ & 480 & 813 \\
\hline 11 & Wr. Dpk 2 Tengah & 600 & 994 & 36 & $\begin{array}{l}\text { Wr. Sembako Ibu } \\
\text { Nyai }\end{array}$ & 480 & 813 \\
\hline 12 & $\begin{array}{l}\text { Wr. Sumber Rezeki } \\
\text { Snack Srengseng }\end{array}$ & 480 & 813 & 37 & $\begin{array}{l}\text { Wr. Sembako } \\
\text { Sumber rezeki }\end{array}$ & 600 & 994 \\
\hline 13 & $\begin{array}{l}\text { Wr. Snack Kukusan } \\
\text { Beji }\end{array}$ & 360 & 630 & 38 & $\begin{array}{l}\text { Wr. Kelontong H. } \\
\text { Sueb }\end{array}$ & 600 & 994 \\
\hline 14 & Wr. Lulu & 600 & 994 & 39 & Wr. Bakti Jaya & 480 & 813 \\
\hline 15 & $\begin{array}{l}\text { Wr. Sembako Ibu } \\
\text { Hj. Yoyoh }\end{array}$ & 600 & 994 & 40 & Wr. Lima Saudara & 240 & 447 \\
\hline 16 & $\begin{array}{l}\text { Wr. Sembako } \\
\text { Grosir Bhaki Karya }\end{array}$ & 600 & 994 & 41 & Wr. Minoriya & 360 & 630 \\
\hline 17 & Wr. Ko Hasan & 360 & 630 & 42 & Wr. Bpk Wardi & 480 & 813 \\
\hline 18 & Wr. Sinar Baru & 240 & 447 & 43 & Wr. Ucok & 360 & 630 \\
\hline 19 & Wr. Sembako YKS & 600 & 994 & 44 & $\begin{array}{l}\text { Wr. Sembako } \\
\text { Kalimantan }\end{array}$ & 480 & 813 \\
\hline 20 & Wr. El Shirazy & 480 & 813 & 45 & Wr. Madura & 480 & 813 \\
\hline 21 & Wr. Murni & 360 & 630 & 46 & Wr. Yuliana & 240 & 447 \\
\hline 22 & Wr. Tri Jaya & 480 & 813 & 47 & $\begin{array}{l}\text { Wr. Kelontong } \\
\text { Dalimunthe }\end{array}$ & 480 & 813 \\
\hline 23 & Wr. Bhakti Karya & 480 & 813 & 48 & $\begin{array}{l}\text { Wr. Empat } \\
\text { Bersaudara }\end{array}$ & 480 & 813 \\
\hline 24 & Wr. Kelontong Abi & 600 & 994 & 49 & $\begin{array}{l}\text { Wr. Kelontong } \\
\text { Tasya Kembang }\end{array}$ & 480 & 813 \\
\hline 25 & Wr. Kelontong Yadi & 480 & 813 & 50 & Wr. Bu Abbas & 360 & 630 \\
\hline
\end{tabular}
2 results of Calculation of Lot Size Ordering Traditional Model Buyers.

Table 2. Calculation of lot size for traditional model buyer order result

3. Calculating Total Cost of Buyer 
After obtaining the economic order lot size for each stall, then the next Total Buyer Cost can be known. The following example is a calculation using Data first stall (Wr. Wati).

Total Cost of Buyer $=$ Order cost + Holding cost + Shortage cost

$$
\begin{aligned}
= & \left(\frac{\text { demand level }}{\text { order lot size }} \times \text { order cost per order }\right) \\
& \quad+(\text { average inventory at supplier } \times \text { holding cost per pcs } / \text { periode }) \\
& \quad+(\text { shortage quantity } \times \text { shortage cost to buyer })
\end{aligned}
$$

\begin{tabular}{|c|c|c|c|c|c|}
\hline No. & List of Stall & $\begin{array}{c}\text { Total Cost } \\
\text { of Buyer } \\
\text { (Rp) }\end{array}$ & No. & List of Stall & $\begin{array}{c}\text { Total Cost } \\
\text { of Buyer } \\
\text { (Rp) }\end{array}$ \\
\hline 1 & Wr. Wati & 44,219 & 26 & Wr. Kelontong Ibu Nuryanti & 31,376 \\
\hline 2 & Wr. Lestari & 44,219 & 27 & Wr. Kelontong Esa & 31,376 \\
\hline 3 & Wr. Lokes Psr lama & 33,542 & 28 & Wr. Kelontong Mulya & 31,376 \\
\hline 4 & Wr. Dodo Psr kemiri & 37,128 & 29 & Wr. Kelontong Ar Raihan & 33,542 \\
\hline 5 & Wr. Iwan Psr kemiri & 33,542 & 30 & Wr. Sembako Bpk Wardi & 31,376 \\
\hline 6 & Wr. Luna Psr kemiri & 31,376 & 31 & Wr. Kelontong Barokah & 31,376 \\
\hline 7 & Wr. Gun 1 Psr kemiri & 31,376 & 32 & Wr. Kelontong Sugiti & 37,128 \\
\hline 8 & Wr. Gun 2 Psr kemiri & 37,128 & 33 & Wr. Sembako Murni & 33,542 \\
\hline 9 & Wr. Asep Psr kemiri & 33,542 & 34 & Wr. Mba Ajeng & 37,128 \\
\hline 10 & Wr. Triyanto Psr Baru & 33,542 & 35 & Wr. Kelongont Lima Jaya & 33,542 \\
\hline 11 & Wr. Dpk 2 Tengah & 31,376 & 36 & Wr. Sembako Ibu Nyai & 33,542 \\
\hline 12 & $\begin{array}{l}\text { Wr. Sumber Rezeki Snack } \\
\text { Srengseng }\end{array}$ & 33,542 & 37 & Wr. Sembako Sumber rezeki & 31,376 \\
\hline 13 & Wr. Snack Kukusan Beji & 37,128 & 38 & Wr. Kelontong H. Sueb & 31,376 \\
\hline 14 & Wr. Lulu & 31,376 & 39 & Wr. Bakti Jaya & 33,542 \\
\hline 15 & Wr. Sembako Ibu Hj. Yoyoh & 31,376 & 40 & Wr. Lima Saudara & 44,219 \\
\hline 16 & $\begin{array}{l}\text { Wr. Sembako Grosir Bhaki } \\
\text { Karya }\end{array}$ & 31,376 & 41 & Wr. Minoriya & 37,128 \\
\hline 17 & Wr. Ko Hasan & 37,128 & 42 & Wr. Bpk Wardi & 33,542 \\
\hline 18 & Wr. Sinar Baru & 44,219 & 43 & Wr. Ucok & 37,128 \\
\hline 19 & Wr. Sembako YKS & 31,376 & 44 & Wr. Sembako Kalimantan & 33,542 \\
\hline 20 & Wr. El Shirazy & 33,542 & 45 & Wr. Madura & 33,542 \\
\hline 21 & Wr. Murni & 37,128 & 46 & Wr. Yuliana & 44,219 \\
\hline 22 & Wr. Tri Jaya & 33,542 & 47 & Wr. Kelontong Dalimunthe & 33,542 \\
\hline 23 & Wr. Bhakti Karya & 33,542 & 48 & Wr. Empat Bersaudara & 33,542 \\
\hline 24 & Wr. Kelontong Abi & 31,376 & 49 & $\begin{array}{l}\text { Wr. Kelontong Tasya } \\
\text { Kembang }\end{array}$ & 33,542 \\
\hline 25 & Wr. Kelontong Yadi & 33,542 & 50 & Wr. Bu Abbas & 37,128 \\
\hline
\end{tabular}

The results of the calculation of the Total Cost of Buyers for other stalls can be seen in Table 3 .

Table 3. Results of the calculation of the total cost of buyers

3.4 Calculation with Vendor Managed Inventory (VMI) Model

To make arrangements for delivery schedules and the large number of products that must be delivered to each stall, the VMI Model is applied. The Buyer's Order Cost consists of the Administration Order Cost, the Transportation Cost, and the Product Ownership Cost for the Buyer. 
Decision Variable:

$Q_{p} *$ : Economic order lot size of the supplier $(\mathrm{kg})$

$Q_{b} *$ : Economic order lot size of the Buyer (pcs)

$m_{p} *$ : Frequency of delivery from suppliers to buyers

Parameter

$D$ : Demand level of the Buyer (pcs)

$A_{a b} \quad$ : Administration order cost $=$ Rp. 0

$A_{u b} \quad$ : Transportation cost $=$ Rp. $1,000 /$ order

$A_{u b} \quad:$ Ongkos kepemilikan produk pembeli $=$ Rp.6,000 $/$ pack

$A_{b} \quad:$ Total order cost of buyer $=$ Rp.7,000/order

$A_{p} \quad$ : Total order cost of supplier $=$ Rp.30,000/order

$h_{p}$ : Total finished product holding cost of supplier $=\mathrm{Rp} .100 / \mathrm{pcs} / \mathrm{month}$

$h_{b}$ : Total finished product holding cost of buyer $=$ Rp.63 $/ \mathrm{pcs}$

$P_{p}:$ The purchase price of raw materials at the supplier $=\mathrm{Rp} .3,000 / \mathrm{kg}$

$P_{b}$ : The purchase price of the finished product $=\mathrm{Rp} .24,000 / \mathrm{pack}$

$\mathrm{Cu}_{p} \quad$ : Shortage cost from the supplier to Buyer $=\mathrm{Rp} .750 / \mathrm{kg}$

$C u_{b} \quad:$ Shortage cost of Buyer $=\mathrm{Rp} .750 / \mathrm{kg}$

$N_{p} \quad$ : Shortage quantity of supplier $=210$ pack

$N_{b} \quad$ : Shortage quantity of Buyer $=216$ pack

$S S_{p} \quad:$ Safety stock supplier $=839 \mathrm{~kg}$

$S S_{b} \quad:$ Safety stock buyer $=261$ pcs

$\alpha_{p} \quad$ : Shortage of inventory probability of supplier $=0.01$

$\alpha_{b} \quad$ : Shortage of inventory probability of buyer $=0.03$

$z(\alpha)_{p} \quad$ :Value of $\mathrm{z}$ distribution for the shortage of inventory event probability of supplier $=2.33$

$z(\alpha)_{b}$ : Value of $\mathrm{z}$ distribution for the shortage of inventory event probability of buyer $=1.88$

$f(z \alpha)_{p}:$ Function value $\alpha$ of supplier $=0.0283$

$f(z \alpha)_{b}$ : Function value $\alpha$ of buyer $=0.0790$

$\psi(z \alpha)_{p}:$ Partial Expectation $\alpha$ of supplier $=0.0037$

$\psi(z \alpha)_{b}:$ Partial Expectation $\alpha$ of Buyer $=0.0143$

3.5 Calculation of Buyer Economic Order Quantity, Supplier Economic Order Quantity, and Optimal Delivery Frequency for Suppliers

In order obtaining the optimal number of economic order sizes for buyers and suppliers with the optimal shipping frequency for suppliers, it can be done using the following formula:

$$
\begin{array}{rl}
m_{p} & *=\sqrt{\frac{h_{b}\left(A_{p}+C u_{p} N\right)}{h_{p} A_{b}}} \\
& =\sqrt{\frac{63(30,000+750 \times 216)}{100 \times 7,000}} \\
& =4,15 \approx 4 \text { times delivery per month } \\
Q_{b} & *=\sqrt{\frac{2 D\left(A_{p}+C u_{p} N+m A_{b}\right)}{m\left(h_{p} m+h_{b}\right)}} \\
= & \sqrt{\frac{2 \times 240(30,000+750 \times 216+4 \times 7,000)}{4(100 \times 4+63)}} \\
= & 231,86 \approx 232 \text { pcs per month } \\
Q_{p} * & =m_{p} Q_{b} \\
Q_{p} * & =928 \mathrm{~kg} \text { per month }
\end{array}
$$

The VMI model calculation to determine the lot size of buyers and supplier's economic order and the frequency of delivery from suppliers to buyers for other stalls can be seen in Table 4 .

Table 4. Calculation results using the VMI model 


\begin{tabular}{|c|c|c|c|c|}
\hline No. & List of Stall & $\begin{array}{l}\text { Delivery } \\
\text { Frequency }\end{array}$ & $\begin{array}{l}\text { Order Lot Sizing } \\
\text { for Buyer }\end{array}$ & $\begin{array}{l}\text { Order Lot Sizing } \\
\text { for Supplier }\end{array}$ \\
\hline 1 & Wr. Wati & 4 & 232 & 928 \\
\hline 2 & Wr. Lestari & 4 & 232 & 928 \\
\hline 3 & Wr. Lokes Psr lama & 3 & 464 & 1392 \\
\hline 4 & Wr. Dodo Psr kemiri & 3 & 348 & 1044 \\
\hline 5 & Wr. Iwan Psr kemiri & 3 & 464 & 1392 \\
\hline 6 & Wr. Luna Psr kemiri & 3 & 580 & 1740 \\
\hline 7 & Wr. Gun 1 Psr kemiri & 3 & 580 & 1740 \\
\hline 8 & Wr. Gun 2 Psr kemiri & 3 & 348 & 1044 \\
\hline 9 & Wr. Asep Psr kemiri & 3 & 464 & 1392 \\
\hline 10 & Wr. Triyanto Psr Baru & 3 & 464 & 1392 \\
\hline 11 & Wr. Dpk 2 Tengah & 3 & 580 & 1740 \\
\hline 12 & Wr. Sumber Rezeki Snack Srengseng & 3 & 464 & 1392 \\
\hline 13 & Wr. Snack Kukusan Beji & 3 & 348 & 1044 \\
\hline 14 & Wr. Lulu & 3 & 580 & 1740 \\
\hline 15 & Wr. Sembako Ibu Hj. Yoyoh & 3 & 580 & 1740 \\
\hline 16 & Wr. Sembako Grosir Bhaki Karya & 3 & 580 & 1740 \\
\hline 17 & Wr. Ko Hasan & 3 & 348 & 1044 \\
\hline 18 & Wr. Sinar Baru & 4 & 232 & 928 \\
\hline 19 & Wr. Sembako YKS & 3 & 580 & 1740 \\
\hline 20 & Wr. El Shirazy & 3 & 464 & 1392 \\
\hline 21 & Wr. Murni & 3 & 348 & 1044 \\
\hline 22 & Wr. Tri Jaya & 3 & 464 & 1392 \\
\hline 23 & Wr. Bhakti Karya & 3 & 464 & 1392 \\
\hline 24 & Wr. Kelontong Abi & 3 & 580 & 1740 \\
\hline 25 & Wr. Kelontong Yadi & 3 & 464 & 1392 \\
\hline 26 & Wr. Kelontong Ibu Nuryanti & 3 & 580 & 1740 \\
\hline 27 & Wr. Kelontong Esa & 3 & 580 & 1740 \\
\hline 28 & Wr. Kelontong Mulya & 3 & 580 & 1740 \\
\hline 29 & Wr. Kelontong Ar Raihan & 3 & 464 & 1392 \\
\hline 30 & Wr. Sembako Bpk Wardi & 3 & 580 & 1740 \\
\hline 31 & Wr. Kelontong Barokah & 3 & 580 & 1740 \\
\hline 32 & Wr. Kelontong Sugiti & 3 & 348 & 1044 \\
\hline 33 & Wr. Sembako Murni & 3 & 464 & 1392 \\
\hline 34 & Wr. Mba Ajeng & 3 & 348 & 1044 \\
\hline 35 & Wr. Kelongont Lima Jaya & 3 & 464 & 1392 \\
\hline 36 & Wr. Sembako Ibu Nyai & 3 & 464 & 1392 \\
\hline 37 & Wr. Sembako Sumber rezeki & 3 & 580 & 1740 \\
\hline 38 & Wr. Kelontong H. Sueb & 3 & 580 & 1740 \\
\hline 39 & Wr. Bakti Jaya & 3 & 464 & 1392 \\
\hline 40 & Wr. Lima Saudara & 4 & 232 & 928 \\
\hline 41 & Wr. Minoriya & 3 & 348 & 1044 \\
\hline 42 & Wr. Bpk Wardi & 3 & 464 & 1392 \\
\hline 43 & Wr. Ucok & 3 & 348 & 1044 \\
\hline 44 & Wr. Sembako Kalimantan & 3 & 464 & 1392 \\
\hline 45 & Wr. Madura & 3 & 464 & 1392 \\
\hline
\end{tabular}




\begin{tabular}{lllcc}
46 & Wr. Yuliana & 4 & 232 & 928 \\
47 & Wr. Kelontong Dalimunthe & 3 & 464 & 1392 \\
48 & Wr. Empat Bersaudara & 3 & 464 & 1392 \\
49 & Wr. Kelontong Tasya Kembang & 3 & 464 & 1392 \\
50 & Wr. Bu Abbas & 3 & 348 & 1044 \\
\hline
\end{tabular}

\subsection{Calculation of Total Buyer and Supplier Costs with VMI}

By implementing the VMI policy whereby the supplier takes over the planning of the order, the Buyer no longer holds the cost of the product shortage and the cost of making the order so that the total costs are borne by the Buyer. Here is an example calculation for the first stall (Wr. Wati):

Total Buyer Cost $=$ Order Receipt Cost + Save Cost

$$
\begin{aligned}
T C_{b}^{V M I} & =\left(\frac{D}{Q_{b}} A_{b}\right)+\left(h_{b} \frac{Q_{b}}{2}\right) \\
& =\left(\frac{240}{232} 7,000\right)+\left(63 \frac{232}{2}\right) \\
& =R p .14,549.37 \approx \text { Rp. } 14,549 \text { per month }
\end{aligned}
$$

Total Cost of Supplier $=$ Order Cost of Supplier + Holding Cost of Supplier + Shortage Cost of Supplier + Administration order cost of Buyer

$$
\begin{aligned}
& T C_{P}^{V M I}=\left(\frac{D_{p}}{m_{p} Q_{b}} A_{p}\right)+\left(h_{p}\left(\frac{1}{2} m_{p} Q_{b}+S S\right)\right)+\left(\frac{C u_{p} D N}{m_{p} Q_{b}}\right)+\left(\frac{D}{Q_{b}} A_{p}\right) \\
& =\left(\frac{200}{928} \times 30,000\right)+\left(100\left(\frac{1}{2} 928+839\right)\right)+\left(\frac{750 \times 200 \times 210}{928}\right)+\left(\frac{240}{232} \times 7,000\right) \\
& \quad=R p .178,208.19 \approx \text { Rp. 178,208 per month }
\end{aligned}
$$

\section{Conclusions}

1. Inventory policy using the VMI Model is considered to be able to overcome both the shortage and excess of goods due to demand uncertainty and limited information provided. With the VMI model, buyers can collaborate with suppliers in inventory planning to reduce the risk of unsold products and shortages of goods. On the supplier side, the supplier can easily find out the distribution planning to each Warung so that it can encourage the development of its business units.

2. Total costs incurred by UD. Sari Jaya in ordering raw materials to suppliers using the Traditional model of Rp. 170,503 per month and using a VMI model of Rp. 186,370 per month, or in other words, increases with the risk and additional ordering activities taken over by the supplier.

3. UD. Sari Jaya should be able to find additional suppliers of cassava raw materials if there is a higher demand for UD. Sari Jaya can maximize the benefits obtained.

\section{References}

[1] Apriyani, N., \& A. Muhsin. Analisis Pengendalian Persediaan Bahan Baku Dengan Metode Economic Order Quantity Dan Kanban Pada Pt Adyawinsa Stamping Industries JURNAL OPSI-Optimasi Sistem Industri. 2017;10(2), 128-142.

[2] Bahagia, S. N. (2006). Sistem Inventori. Bandung: Penerbit ITB.

[3] Darwish, M.A., \& Odah, O.M. Vendor managed inventory model for single-vendor multi-retailer supply chains. European Journal of Operational Research. 2010;204(3). 473-484.

[4] Hayati, E. N. Supply Chain Management (SCM) dan Logistic Management. Jurnal Dinamika Teknik, 2014;8(1), $25-34$.

[5] Parwati, Indri., \& Andrianto, P. Metode Supply Chain Management Untuk Menganalisis Bullwhip Effect Guna Meningkatkan Efektivitas Sistem Distribusi Produk. Jurnal Teknologi, 2009;2(1), 47 - 52.

[6] Putra, S., et al. Analisis Industri Pangan Sub Sektor Industri Makanan Ringan Kue Bangkit Dan Bolu (Dengan Menggunakan Strukture Conduct Performance/SCP). Jurnal Online Mahasiswa (JOM) Bidang Ilmu Ekonomi. 2016;4(1), 558-569. 
[7] Poorbagheri, T., \& Niaki, S. T. A. Vendor Managed Inventory of a Single-vendor Multiple-retailer Single-warehouse Supply Chain under Stochastic Demands. International Journal of Supply and Operations Management. 2014;1(4), 297 - 313.

[8] Pulungan, D.S., \& Fatma, E. Analisis Pengendalian Persediaan Menggunakan Metode Probabilistik dengan Kebijakan Backorder dan Lost sales. Jurnal Teknik Industri. 2018; 19(1), 28 - 48.

[9] Sitompul, Carles., Ariningsih, P.K., \& Santosa, I.B.D.N. "Pengembangan Model Vendor Managed Inventory dengan Banyak Retailer yang Mempertimbangkan Ketidakpastian Lead Times". Jurnal Rekayasa Sistem Industri. 2018;7(1), 41 - 46.

[10] Trihudiyatmanto, M. Analisis Pengendalian Persediaan Bahan Baku Dengan Menggunakan Metode Economic Order Quantity (Eoq)(Studi Empiris Pada Cv. Jaya Gemilang Wonosobo). Jurnal Penelitian dan Pengabdian Kepada Masyarakat UNSIQ. 2017;4(3), 220-234.

[11] Turang, Rinaldo., \& Suseno, D.E. Sistem Kontrol Inventori Pemasokan Barang Secara Real Time Menggunakan Vendor Managed Inventory (VMI) dan Short Massage Service (SMS). Jurnal Sistem Informasi Bisnis. 2014;2, 139 - 147.

[12] Yosefa., Sitompul, C., \& Alfian. Perancangan Model VMI (Vendor Managed Inventory) dengan Satu Pemasok dan Banyak Retailer yang Meminimasi Ongkos Total Rantai Pasok. Jurnal Rekayasa Sistem Industri. 2015;5(2), 88 - 96. 